\title{
Molecular and Functional Characterization of Bacopa monniera: A Retrospective Review
}

\author{
Koilmani Emmanuvel Rajan, ${ }^{1}$ Jayakumar Preethi, ${ }^{1}$ and Hemant K. Singh ${ }^{2}$ \\ ${ }^{1}$ Department of Animal Science, School of Life Sciences, Bharathidasan University, Tiruchirappalli 620024, India \\ ${ }^{2}$ Laboratories for CNS Disorder, Learning \& Memory, Division of Pharmacology, Central Drug Research Institute, \\ Lucknow 226001, India
}

Correspondence should be addressed to Koilmani Emmanuvel Rajan; emmanuvel1972@yahoo.com

Received 10 October 2014; Revised 24 March 2015; Accepted 9 April 2015

Academic Editor: Francesca Borrelli

Copyright (C) 2015 Koilmani Emmanuvel Rajan et al. This is an open access article distributed under the Creative Commons Attribution License, which permits unrestricted use, distribution, and reproduction in any medium, provided the original work is properly cited.

Over the last 50 years, laboratories around the world analyzed the pharmacological effect of Bacopa monniera extract in different dimensions, especially as a nerve tonic and memory enhancer. Studies in animal model evidenced that Bacopa treatment can attenuate dementia and enhances memory. Further, they demonstrate that Bacopa primarily either acts via antioxidant mechanism (i.e., neuroprotection) or alters different neurotransmitters (serotonin (5-hydroxytryptamine, 5-HT), dopamine (DA), acetylcholine (ACh), $\gamma$-aminobutyric acid (GABA)) to execute the pharmacological effect. Among them, 5-HT has been shown to fine tune the neural plasticity, which is a substrate for memory formation. This review focuses on the studies which trace the effect of Bacopa treatment on serotonergic system and 5-HT mediated key molecular changes that are associated with memory formation.

\section{Introduction}

Bacopa monniera (L.) Wettst., which belongs to the family Scrophulariaceae, is an annual creeping plant found in wet, damp, and marshy areas. The leaves and stem of the plant are used for medicinal purposes traditionally [1]. In the ancient Indian system of medicine, namely, Ayurveda, $B$. monniera known as "Bhrami" has been classified under Medhya Rasayana and described in ancient ayurvedic medical encyclopedias, namely, Charaka Samhita, Sushrutha Samhita, and Astanga Hrdaya, as cure for mental disorders and loss of intellect and memory. It has been tested in different animal models to understand its effect on memory $[2,3]$ and antiamnesic activity [4-9]. These pharmacological properties lead to clinical trial of $B$. monniera extract in elderly persons to improve cognitive performance and memory [10-15]. In parallel, Bacopa is a main constituent in the preparation of ayurvedic medicine prescribed for cognitive dysfunction. In addition, several research groups and pharmaceutical companies formulated Bacopa for clinical use in different countries including India, New Zealand, Australia, and United States of America. Earlier, many reviews have discussed pharmacological property of B. monniera in a broad perspective; however, no comprehensive article has yet shown its effect on molecular level. In this review, we summarize the in vivo experiments that suggest that $B$. monniera treatment enhances cognitive function by altering the molecular targets through serotonergic system.

\section{Bioactive Compounds in \\ B. monniera Leaf Extract}

Series of biochemical studies identified different pharmacological compounds from ethanolic extracts of Bacopa, which include alkaloids (brahmine, nicotine, and herpestine), saponins (monnierin, hersaponin), sterols (b-sitosterol, stigma-sterol), d-mannitol, acid A, and betulinic acid [1618]. The principal constituents of $B$. monniera are triterpene saponins of the dammarane class, which have been named bacosides and bacopasaponins. There are two types of 
saponins, jujubogenin and pseudojujubogenin, which differ only in the nature of the sugar units in the glycosidic chain and the position of the olefinic side chain in the aglycone. These saponins are complex mixture of closely related structures, namely, bacosides $A_{1}$ [19] and $A_{3}$ [20] and bacopasaponins A-G [21-23]. Two new dammaranetype jujubogenin bisdesmosides, bacopasaponins $\mathrm{E}$ and $\mathrm{F}$ [24], pseudojujubogenin glycosides, bacopasides I and II [25], phenylethanoid glycosides, namely, monnierasides I-III with the known analogue plantainoside B [26], and bacopasides III, IV, and V [27] have also been identified. The major chemical entity shown responsible for neuropharmacological effects of B. monniera is bacoside A (64.28\%) and bacoside $\mathrm{B}(27.11 \%)$; the latter differs only in optical rotation. The bacoside A (bacogenins A1, A2, A3, and A4) derives from two triterpenoid saponins: pseudojujubogenin and jujubogenin on acid hydrolysis [16-18, 28]. All these bacogenins (especially A4) are rich in the standardized extract of Bacopa which is termed as bacosides-enriched standardized extract of Bacopa (BESEB CDRI-08) that contains $55 \pm 5 \%$ bacosides (Lumen Marketing Company, Chennai, India), and BESEB CDRI-08 is mentioned as BME in this paper.

\section{Neuropharmacological Activity of BME}

3.1. Learning and Memory. Bacopa treatment has been reported to improve behavior of different laboratory animal models under variety of experimental conditions. Oral administration of BME improved spatial learning of rats and mice in Morris water maze [4, 5, 29-31]. Interestingly, several other studies demonstrated that it also improved spatial working memory in different mazes like plus maze $[32,33]$, Y-maze [34, 35], radial arm maze [34, 36], Barnes maze [36], T-maze [37], Hole board [35], and modified Y maze [38]. In addition, it also improved negative reinforcement (footshock motivated brightness discrimination task, conditioned avoidance response) and positive reinforcement (conditioned taste aversion) based memory [2, 39]. Similarly, in passive avoidance task and fear conditioning task Bacopa treatment increased the transfer latency and freezing response [33, $35,37,38,40-42]$, whereas, in contextual cues associated with odor, BME treated rats showed less latency to retrieve the reward [43] and exhibited improved discrimination of novel object $[38,44,45]$. In addition, it has been stated that Bacopa treatment induced dendritic arborization of neurons in hippocampal and basolateral amygdala [46, 47], which possibly enhanced neural plasticity.

\section{B. monniera Extract Treatment Ameliorates Chemicals Induced Dementia}

Interestingly, several studies investigated the pharmacological effect of BME against different chemical compounds that induce anterograde/retrograde amnesia by targeting different neuronal system. These studies reported that BME effectively attenuated anterograde/retrograde amnesia induced by chemical compounds such as scopolamine, an acetylcholine receptor antagonist $[2,6,7,22,36,40,48,49]$, diazepam, a positive allosteric modulators of $\gamma$-aminobutyric acid (GABA) type A receptor [4], $\mathrm{N}_{\omega}$-nitro-l-arginine (L-NNA), a nitric oxide synthase inhibitor [8, 9], BN52021, a receptor antagonist for platelet activating factor [48], and sodium nitrite, a anticholinergic drug [48]. In addition, memory impairments caused by Okadaic acid, a selective inhibitor of protein phosphatase [31], aluminium-chloride which causes oxidative damage [50], autistic symptoms induced by sodium valproate, a weak blocker of sodium ion channels, and inhibitor of GABA transaminase [51] were also ameliorated by Bacopa treatment.

\section{Uptake of Bacosides}

We have learned from pioneering works about different active compounds in B. monniera extract [16-18]. As a first step to validate the effect of BME on the reported behavioral improvements, Charles et al. [35] confirmed that orally treated BME was uptaken into the system. HPLC analysis showed the presence of bioactive compound bacoside $\mathrm{A}$ in the serum of BME treated rats. The bioactive compounds in the BME could directly or indirectly interact with neurotransmitter systems to enhance learning and memory. Since the bacosides present in the BME are nonpolar glycosides [2527], they can cross the blood-brain barrier (BBB) by simple lipid-mediated passive diffusion [52], and its bioavailability in brain has been confirmed by the biodistribution of radiopharmaceuticals [53] effectively activating the cascade which participates in the memory enhancing mechanism.

\section{Activation of Neurotransmitter Systems by Bacoside}

The balanced functions of various neurotransmitters such as acetylcholine (ACh) [2, 40], serotonin (5-hydroxytryptamine, 5-HT) [2, 54], catecholamine [55], $\gamma$ aminobutyric acid (GABA) [56], and glutamate (Glu) [8] were all altered by $\mathrm{BME}$ treatment. It has been reported that the BME treatment increased the 5-HT level in the hippocampus, hypothalamus, and cerebral cortex [54], and also modified the $\mathrm{ACh}$ concentration directly/indirectly through other neurotransmitter systems. As a first step, Rajan et al. [41] estimated the level of neurotransmitters to understand the effect of BME treatment. They found that BME treatment during postnatal period significantly upregulated the level of 5-HT, ACh, GABA, and Glu. In contrast, it reduced the level of dopamine (DA). Notably, the reported inhibitory effects of cholinesterase activity of BME may possibly increase the level of ACh and enhance memory $[33,40]$. On the other hand, 5-HT receptors present in the GABAergic neuron [57] may activate the GABAergic neurons $[58,59]$, which enhances the release of GABA. In fact, increased GABA level in hippocampus could activate the inhibitory GABA receptors on cholinergic system that leads to inhibition of ACh release [60,61], but 5-HT receptors may directly act on the cholinergic system and increase release of Ach [62]. These proceedings and the observed trend in the 5-HT level have drawn the attention to analyse the effect of BME on 5-HT system. Further, studies were designed to test the pathway associated with 5-HT system (Figure 1). Observed effect of BME on neurotransmitter systems and 


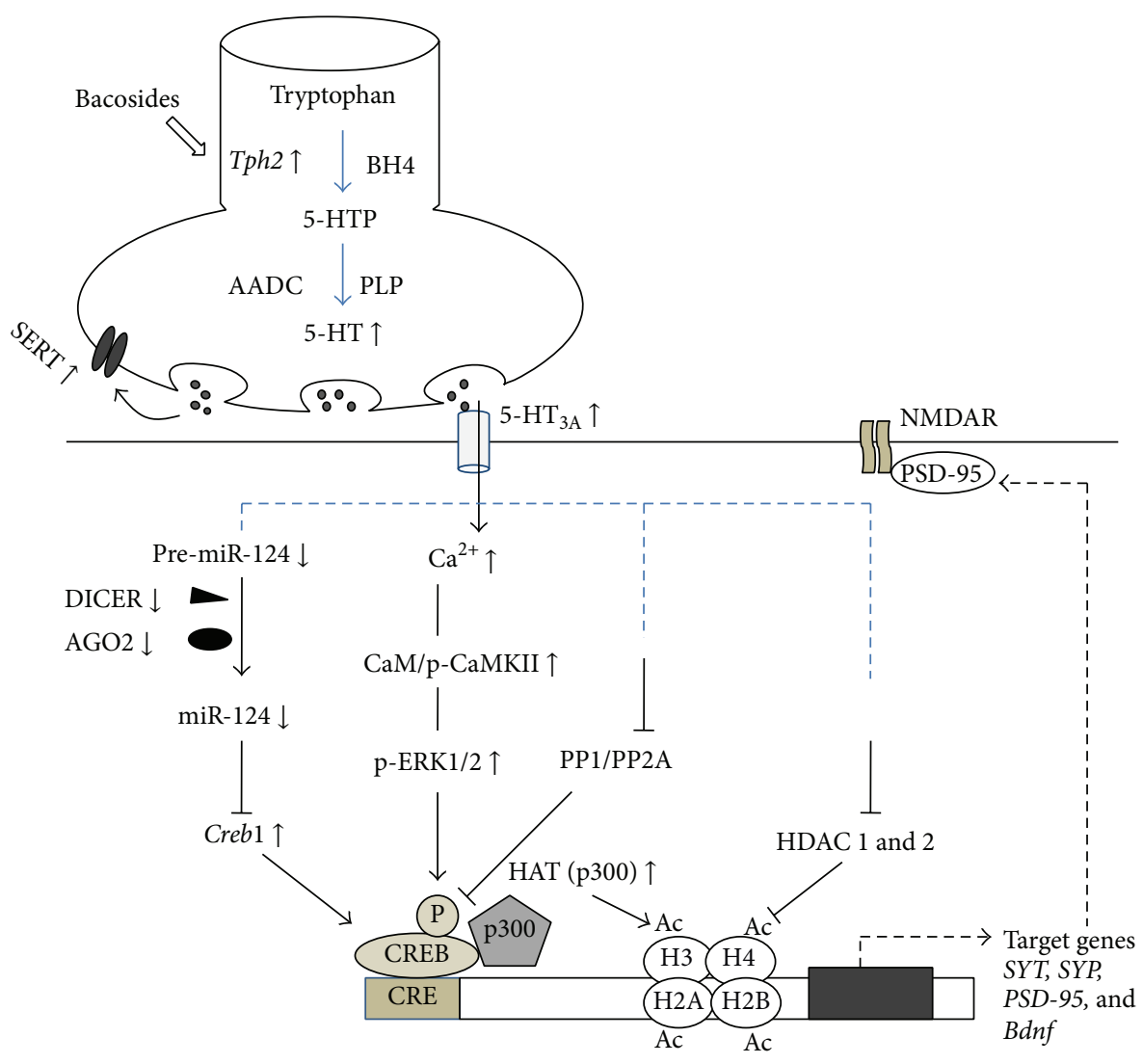

FIGURE 1: Diagram showing the possible mechanism of serotonin mediated signaling pathway activated by BME during learning. ( $\uparrow:$ increase; $\downarrow$ : decrease).

the molecules involved in the signaling pathway are shown in Table 1.

\section{BME Treatment Regulates the Synthesis of Serotonin}

Earlier studies demonstrated that increasing level of tryptophan hydroxylase (TPH) mRNA expression elevated TPH activity and 5-HT metabolism, which profoundly could influence the synaptic 5-HT activity $[63,64]$. Further, serotonin transporter (SERT) is known to critically uptake the 5-HT by transport across presynaptic membrane [65]. The upregulated level of 5-HT by BME raises the question, does it alter the level of TPH2 and SERT? Interestingly, Charles et al. [35] showed that TPH2, SERT mRNA expression was upregulated and the level persisted even a week after the BME treatment [35]. The upregulated SERT expression could regulate the reuptake of released 5-HT and control the duration and intensity of serotonergic activity at the synapse. This could be one of the mechanisms that enhance the learning and memory processing and it fits well into established concept in different models $[66,67]$. In addition to these studies, in silico analysis suggested that interaction of bacosides $\left(A, A_{3}\right)$ with TPH2 possibly alters the activity of TPH2 that could be one of the mechanisms for increased 5-HT synthesis [68].

\section{Activation of 5-HT Receptor by BME Treatment}

Previously, it has been found that synaptically released 5HT exerts its function through their diverse receptors [69]. Activated receptors either positively or negatively regulate the downstream signaling cascade that is involved in regulation of synaptic plasticity [70-72]. In view of these reports, expression of 5- $\mathrm{HT}$ receptors $\left(5-\mathrm{HT}_{1 \mathrm{~A}}, 5-\mathrm{HT}_{2 \mathrm{~A}}\right.$, $5-\mathrm{HT}_{4}, 5-\mathrm{HT}_{5 \mathrm{~A}}, 5-\mathrm{HT}_{6}$, and $5-\mathrm{HT}_{7}$ ) after BME treatment was examined. Notably, $5-\mathrm{HT}_{3 \mathrm{~A}}$ receptor expression was increased compared to all other receptors. It is the only metabotropic receptor, and its expression could be stimulated by endogenous 5 -HT which may facilitate the hippocampaldependent task $[73,74]$. Hence, the role of $5-\mathrm{HT}_{3 \mathrm{~A}}$ in hippocampal-dependent learning could be tested by using $5-\mathrm{HT}_{3}$ antagonist 1-( $m$-chlorophenyl)-biguanide ( $m \mathrm{CPBG}$ ), which effectively impairs the retention of the conditioned response [75] in both short- and long-term memories [76]. The 5- $\mathrm{HT}_{3}$ antagonist $m \mathrm{CPBG}$ has facilitated gaining insight into the $\mathrm{BME}$ induced $5-\mathrm{HT}_{3 \mathrm{~A}}$ receptor mediated role in 
TABLE 1: Summary of Bacopa monniera treatment effects on serotonergic system and its associated pathway.

\begin{tabular}{|c|c|c|c|c|c|c|}
\hline Neurotransmitters & Effects & $\begin{array}{c}\text { Genes } \\
\text { (mRNA) }\end{array}$ & Effects & $\begin{array}{c}\text { Genes } \\
\text { (Protein) }\end{array}$ & Effects & References \\
\hline \multirow{2}{*}{ Serotonin } & \multirow{2}{*}{$\uparrow$} & Tph2 & $\uparrow$ & & & \multirow{2}{*}[35]{} \\
\hline & & SERT & $\uparrow$ & & & \\
\hline \multirow{26}{*}{$\begin{array}{l}\text { Serotonin } \\
\text { Dopamine } \\
\text { Acetylcholine } \\
\text { GABA } \\
\text { Glutamate }\end{array}$} & \multirow{7}{*}{$\begin{array}{l}\uparrow \\
\downarrow \\
\uparrow \\
\uparrow \\
\uparrow\end{array}$} & $5-H T 1_{A}$ & - & & & \multirow{7}{*}[41]{} \\
\hline & & $5-H T 2_{A}$ & $\uparrow$ & & & \\
\hline & & $5-H T 3_{A}$ & $\uparrow$ & & & \\
\hline & & 5-HT4 & - & & & \\
\hline & & 5-HT5 & - & & & \\
\hline & & 5-HT6 & - & & & \\
\hline & & 5-HT7 & $\downarrow$ & & & \\
\hline & & \multirow{5}{*}{ Nrf2 } & \multirow{5}{*}{$\uparrow$} & SYP & $\uparrow$ & \multirow{5}{*}[43]{} \\
\hline & & & & SYT & $\uparrow$ & \\
\hline & & & & t- $\alpha$ CaMKII & $\uparrow$ & \\
\hline & & & & p- $\alpha$ CaMKII & $\uparrow$ & \\
\hline & & & & PSD-95 & $\uparrow$ & \\
\hline & & Dicer & $\downarrow$ & DICER & $\downarrow$ & \multirow{4}{*}{ [39] } \\
\hline & & Ago2 & $\downarrow$ & AGO2 & $\downarrow$ & \\
\hline & & $m i R-124$ & $\downarrow$ & $\mathrm{t}-\mathrm{CREB} 1 / 2$ & $\uparrow$ & \\
\hline & & Creb1 & $\uparrow$ & $\mathrm{p}$-CREB1/2 & $\uparrow$ & \\
\hline & & \multirow{10}{*}{$\begin{array}{l}B d n f \\
P P 1 \alpha\end{array}$} & \multirow{10}{*}{$\begin{array}{l}\uparrow \\
\downarrow\end{array}$} & $\mathrm{t}-\mathrm{ERK} 1 / 2$ & $\uparrow$ & \multirow{10}{*}[42]{} \\
\hline & & & & p-ERK1/2 & $\uparrow$ & \\
\hline & & & & t-CREB1/2 & $\uparrow$ & \\
\hline & & & & $\mathrm{p}$-CREB1/2 & $\uparrow$ & \\
\hline & & & & Ac-H3 & $\uparrow$ & \\
\hline & & & & Ac- $\mathrm{H} 4$ & $\uparrow$ & \\
\hline & & & & HDAC1 & $\downarrow$ & \\
\hline & & & & HDAC2 & $\downarrow$ & \\
\hline & & & & p300 & $\uparrow$ & \\
\hline & & & & PP2A & $\downarrow$ & \\
\hline
\end{tabular}

$\downarrow$ : decrease; $\uparrow:$ increase.

hippocampal-dependent learning and its regulation of other neurotransmitters. Interestingly, treatment of BME ameliorated the antagonistic effect of $m C P B G$. The combination of $m \mathrm{CPBG}$ and $\mathrm{BME}$ treatment recorded improvement in behavioural task accompanying the upregulation of $5-\mathrm{HT}_{3 \mathrm{~A}}$ receptor. Considering the interaction of multiple neurotransmitters involved in learning and memory network [77-80], it could be interesting to know the interaction of $5-\mathrm{HT}_{3}$ receptor in activation/inhibition of other neurotransmitter systems.

The upregulated $5-\mathrm{HT}_{3 \mathrm{~A}}$ receptor might regulate serotonergic system and may interact with other neurotransmitters that are involved in learning and memory [58, 67, 81]. It should be noted that $5-\mathrm{HT}_{3 \mathrm{~A}}$ is a heteroreceptor; its stimulation by means of $m \mathrm{CPBG}$ has been reported to enhance GABA and DA levels and inhibit the release of ACh [74]. The activation of $5-\mathrm{HT}_{3}$ receptors in dopaminergic neuron could facilitate the release of DA $[82,83]$, and $m C P B G$ inhibits dopamine uptake by binding with dopamine transporter [84], thereby increasing the synaptic dopamine level. On the other hand, the anticholinesterase activity of BME [40] and other regulatory mechanisms of BME are also involved in the regulation of ACh level and memory enhancement $[33,85]$.

A noteworthy point is that it did not alter the level of Glu. This suggests that glutamate neurons in the hippocampus may not colocalize with $5-\mathrm{HT}_{3 \mathrm{~A}}$ receptor [59]. The observed changes are indication of the facilitatory effect of $\mathrm{BME}$ on long-term and intermediate forms of memory through $5-\mathrm{HT}_{3 \mathrm{~A}}$ receptor.

\section{Activation of Protein Kinases-CREB Pathway}

A pioneering study in 1976 described that serotonin stimulation increases the level of cyclic adenosine monophosphate (cAMP) by the adenyl cyclase in the neuronal cells [86]. Subsequent study by Castellucci et al. [87] established that activation of cAMP mediates downstream signaling process through phosphorylating proteins, namely, cAMP-dependent protein kinase or protein kinase A (PKA). Upon activation, cAMP-dependent PKA dissociates into regulatory and catalytic subunits. The catalytic subunit of 
PKA drives to activate mitogen activated protein kinase (MAPK)/extracellular signal-regulated kinase (ERK1/2) [88, 89]. It has been shown that activation of protein kinases (MAPK/ERK) can induce the phosphorylation of the key transcription factor CREB, which is a positive regulator of memory consolidation [90-93]. These proceedings triggered us to test whether the BME treatment induced activation of $5-\mathrm{HT}_{3 \mathrm{~A}}$ receptor regulated synaptic plasticity through protein kinase and cAMP response element binding (CREB) protein signaling pathway. It is noteworthy to mention that treatment of BME increased the phosphorylation of ERK1/2 and provides a physiological and functional meaning for the observed different forms of memory [42]. If the p-ERK activity is decreased/increased, one would expect concomitant changes in the CREB and CREB targeted gene expression and functional consequences [94-97]. It should be noted that the induction of p-CREB1 is involved in the regulation of synaptic proteins synthesis, which are known to be involved in synaptic plasticity related events in hippocampus [98] and their synthesis is necessary for the consolidation of long-term memory (LTM) [99-102]. Preethi et al. [39] found that level of both total and phosphorylated CREB protein was increased in the BME treated individuals. When BME treated before $m$-CPBG treatment, the $m$ CPBG mediated suppression of CREB phosphorylation was attenuated by BME, thus adding additional support to the effect of BME in regulation of PKACREB pathway.

\section{Activation of CREB Regulation through MicroRNA-124 by BME}

Long-term memory formation requires synthesis of new proteins $[103,104]$, which is regulated by mRNA transport and translation [105]. At this point, several studies proposed that microRNAs (miRNAs) are one of the factors that regulate expression of gene $[106,107]$ which could be regulated by level of miRNA/biosynthesis of miRNA. There are two molecules, Dicer and Ago2, involved in the regulation of miRNA biosynthesis [108]. It is noteworthy to mention that there is an interaction between miR-124 and 5-HT, because the stimulation of the latter has been shown to downregulate the expression of miR-124 during 5-HT-induced synaptic facilitation [109]. Thus, we thought that BME treatment might alter the level of miR-124 expression and the molecules involved in its biosynthesis pathway. Subsequently, we found that BME treatment reduced the level of Dicer, Ago2 mRNA, and protein [39]. Reduction in Dicer has been known to enhance synaptic plasticity [110]; the formation of miRNAinduced silencing complex (miRISC) requires the activation of Ago2 [111]. Further, this study revealed that reduction of Dicer and Ago2 directly downregulated miR-124 level in BME treated individuals. Conversely, inhibition of 5-HT activity by treating with $m$ CPBG showed upregulated Dicer, Ago2, and miR-124 [39]. It has been postulated that the downregulation of miR-124 would lead to the upregulation of CREB [109]. Though it is well established that 5-HT can upregulate Crebl mRNA level [112], recent studies claimed that miR124 might directly bind to Creb1 $3^{\prime} \mathrm{UTR}$ and regulates the expression of CREB $[109,113]$. Indeed, upregulated CREB reciprocally regulates the miRNA $[109,114]$. This in turn regulates the activation of immediate early genes that ultimately facilitates synaptic plasticity [115-118]. These cellular events demonstrate that BME possibly regulates the transcriptional regulators to fine tune transcription factors.

\section{Phosphorylation of CREB Regulated by BME Treatment}

Contrary to the protein kinases, protein phosphatases (PPs) act as dephosphorylating enzymes that dephosphorylate the molecules like CREB [119]. PPs critically regulate the phosphorylation events that favor forgetting [120], cognitive decline in ageing [121, 122], and suppress learning and memory. In brain, several PPs are known to be expressed. Among them, Ser/Thr phosphatases (PP1, PP2) are the most likely candidates that negatively act on the phosphorylation of CREB [123-125] and thereby downregulate the transcription of CREB targeted genes [120, 126, 127]. BME treatment significantly reduced the PP1 $\alpha$ and PP2A level in hippocampus, which appears to be responsible for observed BME mediated enhanced memory [42]. This study revealed the contribution of BME in regulation of CREB phosphorylation that favors the transcription of CREB targeted genes to memory formation. Moreover, it supported the earlier reports which showed inhibition of PPs to enhance memory formation $[120,124,125$, 128-130], but the exact mechanism that inhibits PPs is not yet studied.

\section{Chromatin Modifications Differentially Regulated by BME Treatment}

Studies in memory highlighted chromatin alteration and epigenetic changes that are associated with CREB activation. Contribution of histone tail acetylation and deacetylation in chromatin are widely known to be involved in the formation of long-term memory and synaptic changes [131-133]. Histone deacetylase (HDAC) inhibitors are known to induce acetylation of histones (H3, H4). It has been reported that HDAC inhibitors repress the HDAC-PP1 complex and thus block dephosphorylation of CREB $[134,135]$. On the other hand, in vitro and in vivo studies claimed that transcriptional induction of CREB occurred by pSer133, which requires histone acetylase (HAT) - CREB binding protein (CBP/p300) $[136,137]$. P300 contains intrinsic HAT activity and it has been shown to interact with CREB [138-140]. Manipulation in p300 leads to reduction in the histone acetylation and impairs hippocampus dependent memory [141-143]. These reports prompted us to examine the potential role of BME in chromatin modifications especially with histone acetylation and deacetylation.

An earlier study reported significant enhancement of p300 level in hippocampus of BME treated groups, but not in control groups after training [42]. These reports suggest that BME plays an agonistic role for $\mathrm{p} 300$ in hippocampus; further it may acetylate $\mathrm{H} 3$ and $\mathrm{H} 4$ histones [144-146]. Accordingly, we found that BME treatment induced marked increment in the level of Ac-H3 and Ac-H4 in hippocampus [42]. These results agree with the earlier studies, in which HDAC 
inhibitors have been found to induce acetylation of histones (H3, H4) and improve memory [147-150]. In addition, the level of HDAC 1 and HDAC 2 in the hippocampus of BME treated group was decreased compared to control group. The reduction in HDAC 1 and HDAC 2 levels together with increased acetylation of histones in BME groups added additional evidence to the mechanism of BME [42].

\section{BME Treatment Activates the Synaptic Proteins to Induce Synaptic Plasticity}

Behavioural response to the stimuli is basic functional circuit formation between the neuronal cells. The molecular mechanism underlying the circuit (synaptic plasticity) is likely to provide insight to role of molecules/molecular complexes. The communications between the neuronal cells are initiated by the recruitment of adhesion molecules in pre-post synaptic neurons [151, 152]. Synaptic plasticity depends on activity strength, which leads to release of neurotransmitters to the synaptic cleft. However, the release of neurotransmitters is critically regulated by synaptic proteins synaptotagmin-I (SYT-1) and synaptophysin (SYP). SYT-1 is sensitive to $\mathrm{Ca}^{2+}$ and conserved at least in vertebrates [153]. This synaptic vesicle protein is exclusively involved in synaptic vesicle docking and regulating release of neurotransmitter [154]. Another key synaptic protein SYP is playing important role in regulation of synaptic vesicle association by protein-protein interactions [153]. It is a vesicle-associated regulatory protein which is involved in plasticity related changes in the hippocampus $[155,156]$. The levels of SYT-1 and SYP were upregulated after BME treatment which possibly established the synaptic communication and synaptic function [43]. BME treatment upregulated the synaptic proteins (SYT-1, SYP), which is possibly by the elevated level of 5-HT. The level of signaling components is essential for neurotransmission and synaptic plasticity. The upregulated synaptic proteins could enhance neurotransmission and synaptic plasticity. However, this should be transferred to postsynaptic neurons. There are two key postsynaptic proteins (post synaptic density protein 95 (PSD-95) and $\mathrm{Ca}^{2+} /$ calmodulin dependent protein kinase II (CaMKII)) distributed densely. Acute phosphorylation and localization of PSD-95 and CaMKII is fundamental to synaptic function [157]. They are critical for long-term potentiation (LTP) and information storage $[158,159]$. Translocation of CaMKII to postsynaptic region by autophosphorylation is necessary for early phase of memory formation, where it controls the phosphorylation of different postsynaptic proteins [160]. The induction and phosphorylation of CaMKII depends on the release of 5-HT [161]. Genetic manipulation and pharmacological studies pointed out the critical role of CaMKII in synaptic plasticity and memory formation $[161,162]$. BME treatment upregulated the induction and phosphorylation of CaMKII; it could be by the level of 5-HT, thus the improved memory recorded. PSD-95 is a core component in the architecture of synapses $[163,164]$ involved in localization of receptors, clustering of synaptic signaling proteins, and synapse stabilisation [164-166]. The level of PSD95 increases at synapses during learning/learning-induced plasticity $[167,168]$. Earlier, we demonstrated that PSD95 was upregulated after BME treatment [43]; upregulated PSD-95 may increase the interaction between PSD proteins and enhances synaptic transmission [169-172]. These results suggest that BME treatment activates the synaptic proteins; thus neurotransmission and synaptic plasticity are enhanced between the neurons.

\section{Conclusion}

Taken together, bacosides present in the Bacopa extract has been known to improve cognitive function by modulating different neurotransmitters. However, this review focused on the studies which provide much attention to the serotonergic system, in which, starting from in silico approach to alternation in 5-HT levels, their receptors and associated signaling cascades known to be involved in synaptic plasticity and memory enhancement were discussed. These studies provide molecular evidence to possible mechanism of BME on serotonergic system and its associated pathway.

$\begin{array}{ll}\text { Abbreviations } & \\ \text { 5-HT: } & \text { 5-Hydroxytryptamine } \\ \text { ACh: } & \text { Acetylcholine } \\ \text { BESEB CDRI-08: } & \text { Bacosides-enriched standardized } \\ & \text { extract of Bacopa } \\ \text { CaMKII: } & \text { Ca }^{2+} / \text { calmodulin dependent protein } \\ & \text { kinase II } \\ \text { cAMP: } & \text { Cyclic adenosine monophosphate } \\ \text { CBP: } & \text { CREB binding protein } \\ \text { CREB: } & \text { Cyclic adenosine monophosphate } \\ & \text { (cAMP) response element binding } \\ \text { DA: } & \text { Dopamine } \\ \text { ERK1/2: } & \text { Extracellular signal-regulated kinase } \\ \text { GABA: } & \gamma \text {-Amino butyric acid } \\ \text { Glu: } & \text { Glutamate } \\ \text { HAT: } & \text { Histone acetylase } \\ \text { HDAC: } & \text { Histone deacetylase } \\ \text { L-NNA: } & \text { N }{ }^{-} \text {-nitro-l-arginine } \\ \text { LTM: } & \text { Long-term memory } \\ \text { LTP: } & \text { Long-term potentiation } \\ \text { MAPK: } & \text { Mitogen activated protein kinase } \\ \text { mCPBG: } & \text { 1-(m-Chlorophenyl)-biguanide } \\ \text { miRISC: } & \text { miRNA-induced silencing complex } \\ \text { miRNAs: } & \text { MicroRNAs } \\ \text { PKA: } & \text { Protein kinase A } \\ \text { PPs: } & \text { Protein phosphatases } \\ \text { PSD-95: } & \text { Postsynaptic density protein 95 } \\ \text { SERT: } & \text { Serotonin transporter } \\ \text { SYP: } & \text { Synaptophysin } \\ \text { SYT1: } & \text { Synaptotagmin I } \\ \text { TPH: } & \text { Tryptophan hydroxylase. } \\ & \end{array}$

\section{Conflict of Interests}

The authors have declared that no conflict of interests exists. 


\section{Acknowledgments}

The authors would like to thank the Editors and three anonymous reviewers for their comments to improve the paper. Koilmani Emmanuvel Rajan is thankful to his students Dr. Ganesh Ambigapathy and Dr. Prisila Dulcy Charles for their contribution in developing Bacopa project and Lumen Marketing Company (Chennai, India) for providing the standardised B. monniera extract (CDRI-08). Department of Animal Science is supported by UGC-SAP-DRS-II.

\section{References}

[1] K. M. Mathew, The Flora of Tamil Nadu and Carna, Rapinat Herbarium St. Joseph's College, Tiruchirappalli, India, 1984.

[2] H. K. Singh and B. N. Dhawan, "Neuropsychopharmacological effects of the ayurvedic nootropic Bacopa monniera Linn. (Brahmi)," Indian Journal of Pharmacology, vol. 29, no. 5, pp. S359-S365, 1997.

[3] C. Kongkeaw, P. Dilokthornsakul, P. Thanarangsarit, N. Limpeanchob, and C. N. Scholfield, "Meta-analysis of randomized controlled trials on cognitive effects of Bacopa monnieri extract," Journal of Ethnopharmacology, vol. 151, no. 1, pp. 528-535, 2014.

[4] S. Prabhakar, M. K. Saraf, P. Pandhi, and A. Anand, "Bacopa monniera exerts antiamnesic effect on diazepam-induced anterograde amnesia in mice," Psychopharmacology, vol. 200, no. 1, pp. 27-37, 2008.

[5] M. K. Saraf, A. Anand, and S. Prabhakar, "Scopolamine induced amnesia is reversed by Bacopa monniera through participation of kinase-CREB pathway," Neurochemical Research, vol. 35, no. 2, pp. 279-287, 2010.

[6] M. K. Saraf, S. Prabhakar, P. Pandhi, and A. Anand, "Bacopa monniera ameliorates amnesic effects of diazepam qualifying behavioral-molecular partitioning," Neuroscience, vol. 155, no. 2, pp. 476-484, 2008.

[7] M. K. Saraf, S. Prabhakar, K. L. Khanduja, and A. Anand, "Bacopa monniera attenuates scopolamine-induced impairment of spatial memory in mice," Evidence-Based Complementary and Alternative Medicine, vol. 2011, Article ID 236186, 10 pages, 2011.

[8] M. K. Saraf, S. Prabhakar, and A. Anand, "Bacopa monniera alleviates $\mathrm{N} \omega$-nitro-l-arginine-induced but not MK-801-induced amnesia: A mouse Morris water maze study," Neuroscience, vol. 160, no. 1, pp. 149-155, 2009.

[9] A. Anand, M. K. Saraf, and S. Prabhakar, "Antiamnesic effect of B. monniera on L-NNA induced amnesia involves calmodulin," Neurochemical Research, vol. 35, no. 8, pp. 1172-1181, 2010.

[10] C. Calabrese, W. L. Gregory, M. Leo, D. Kraemer, K. Bone, and B. Oken, "Effects of a standardized Bacopa monnieri extract on cognitive performance, anxiety, and depression in the elderly: a randomized, double-blind, placebo-controlled trial," Journal of Alternative and Complementary Medicine, vol. 14, no. 6, pp. 707-713, 2008.

[11] A. Morgan and J. Stevens, "Does bacopa monnieri improve memory performance in older persons? Results of a randomized, placebo-controlled, double-blind trial," Journal of Alternative and Complementary Medicine, vol. 16, no. 7, pp. 753759, 2010.

[12] C. Stough, A. Scholey, V. Cropley et al., "Examining the cognitive effects of a special extract of Bacopa monniera (CDRI
08: Keenmind): a review of ten years of research at Swinburne University," The Journal of Pharmacy and Pharmaceutical Sciences, vol. 16, no. 2, pp. 254-258, 2013.

[13] U. P. Dave, S. R. Dingankar, V. S. Saxena et al., "An open-label study to elucidate the effects of standardized Bacopa monniera extract in the management of symptoms of attention-deficit hyperactivity disorder in children," Advances in Mind-Body Medicine, vol. 28, pp. 10-15, 2014.

[14] H. C. Barbhaiya, R. P. Desai, V. S. Saxena et al., "Efficacy and tolerability of BacoMind on memory improvement in elderly participants-a double blind placebo controlled study," Journal of Pharmacology and Toxicology, vol. 3, no. 6, pp. 425-434, 2008.

[15] A. Morgan and J. Stevens, "Does Bacopa monnieri improve memory performance in older persons? Results of a randomized, placebo-controlled, double-blind trial," Journal of Alternative and Complementary Medicine, vol. 16, no. 7, pp. 753759, 2010

[16] N. Chatterji, R. P. Rastogi, and M. L. Dhar, "Chemical examination of Bacopa monniera Wettst: isolation of chemical constituent," Indian Journal of Chemistry, vol. 1, pp. 212-215, 1963.

[17] N. Chatterji, R. P. Rastogi, and M. L. Dhar, "Chemical examination of Bacopa monniera Wettst: the constitution of bacoside A," Indian Journal of Chemistry, vol. 3, pp. 24-29, 1965.

[18] N. Basu, P. R. Rastogi, and M. L. Dhar, "Chemical examination of Bacopa monniera Wettst Part III: the constitution of Bacoside-B," Indian Journal of Chemistry, vol. 5, p. 84, 1967.

[19] P. Jain and D. K. Kulshreshtha, "Bacoside $A_{1}$, A minor saponin from Bacopa monniera," Phytochemistry, vol. 33, no. 2, pp. 449$451,1993$.

[20] S. Rastogi, R. Pal, and D. K. Kulshreshtha, "Bacoside A3-a triterpenoid saponin from Bacopa monniera," Phytochemistry, vol. 36, no. 1, pp. 133-137, 1994.

[21] S. Garai, S. B. Mahato, K. Ohtani, and K. Yamasaki, "Dammarane-type triterpenoid saponins from Bacopa monniera," Phytochemistry, vol. 42, no. 3, pp. 815-820, 1996.

[22] S. Garai, S. B. Mahato, K. Ohtani, and K. Yamasaki, "Bacopasaponin $\mathrm{D}$-a pseudojujubogenin glycoside from Bacopa monniera," Phytochemistry, vol. 43, no. 2, pp. 447-449, 1996.

[23] C.-C. Hou, S.-J. Lin, J.-T. Cheng, and F.-L. Hsu, "Bacopaside III, bacopasaponin G, and bacopasides A, B, and C from Bacopa monniera," Journal of Natural Products, vol. 65, no. 12, pp. 17591763, 2002.

[24] S. B. Mahato, S. Garai, and A. K. Chakravarty, "Bacopasaponins $\mathrm{E}$ and F: two jujubogenin bisdesmosides from Bacopa monniera," Phytochemistry, vol. 53, no. 6, pp. 711-714, 2000.

[25] A. K. Chakravarty, T. Sarkar, K. Masuda, K. Shiojima, T. Nakane, and N. Kawahara, "Bacopaside I and II: two pseudojujubogenin glycosides from Bacopa monniera," Phytochemistry, vol. 58, no. 4, pp. 553-556, 2001.

[26] A. K. Chakravarty, T. Sarkar, T. Nakane, N. Kawahara, and K. Masuda, "New phenylethanoid glycosides from Bacopa monniera," Chemical and Pharmaceutical Bulletin, vol. 50, no. 12, pp. 1616-1618, 2002.

[27] A. K. Chakravarty, S. Garai, K. Masuda, T. Nakane, and N. Kawahara, "Bacopasides III-V: three new triterpenoid glycosides from Bacopa monniera," Chemical and Pharmaceutical Bulletin, vol. 51, no. 2, pp. 215-217, 2003.

[28] R. P. Rastogi, Compendium of Indian Medicinal Plants, vol. 1, CSIR, New Delhi, India, 1990.

[29] N. Uabundit, J. Wattanathorn, S. Mucimapura, and K. Ingkaninan, "Cognitive enhancement and neuroprotective effects of 
Bacopa monnieri in Alzheimer's disease model," Journal of Ethnopharmacology, vol. 127, no. 1, pp. 26-31, 2010.

[30] T. Anand, G. P. Kumar, M. D. Pandareesh, M. S. L. Swamy, F. Khanum, and A. S. Bawa, "Effect of bacoside extract from Bacopa monniera on physical fatigue induced by forced swimming," Phytotherapy Research, vol. 26, no. 4, pp. 587-593, 2012.

[31] S. Dwivedi, R. Nagarajan, K. Hanif, H. H. Siddiqui, C. Nath, and R. Shukla, "Standardized extract of Bacopa monniera attenuates okadaic acid induced memory dysfunction in rats: effect on Nrf2 pathway," Evidence-Based Complementary and Alternative Medicine, vol. 2013, Article ID 294501, 18 pages, 2013.

[32] G. S. Achliya, U. Barabde, S. Wadodkar, and A. Dorle, "Effect of Bramhi Ghrita, an polyherbal formulation on learning and memory paradigms in experimental animals," Indian Journal of Pharmacology, vol. 36, no. 3, pp. 159-162, 2004.

[33] H. Joshi and M. Parle, "Brahmi rasayana improves learning and memory in mice," Evidence-Based Complementary and Alternative Medicine, vol. 3, no. 1, pp. 79-85, 2006.

[34] J. Mathew, G. Gangadharan, K. P. Kuruvilla, and C. S. Paulose, "Behavioral deficit and decreased GABA receptor functional regulation in the hippocampus of epileptic rats: effect of Bacopa monnieri," Neurochemical Research, vol. 36, no. 1, pp. 7-16, 2011.

[35] P. D. Charles, G. Ambigapathy, P. Geraldine, M. A. Akbarsha, and K. E. Rajan, "Bacopa monniera leaf extract up-regulates tryptophan hydroxylase (TPH2) and serotonin transporter (SERT) expression: implications in memory formation," Journal of Ethnopharmacology, vol. 134, no. 1, pp. 55-61, 2011.

[36] A. Gupta, M. S. Karchuli, and N. Upmanyu, "Comparative evaluation of ethanolic extracts of Bacopa monnieri, Evolvulus alsinoides, Tinospora cordifolia and their combinations on cognitive functions in rats," Current Aging Science, vol. 6, no. 3, pp. 239-243, 2013.

[37] V. R. Vollala, S. Upadhya, and S. Nayak, "Learning and memory-enhancing effect of Bacopa monniera in neonatal rats," Bratislava Medical Journal, vol. 112, no. 12, pp. 663-669, 2011.

[38] X. T. Le, H. T. N. Pham, P. T. Do et al., “Bacopa monnieri ameliorates memory deficits in olfactory bulbectomized mice: possible involvement of glutamatergic and cholinergic systems," Neurochemical Research, vol. 38, no. 10, pp. 2201-2215, 2013.

[39] J. Preethi, H. K. Singh, P. D. Charles, and K. E. Rajan, "Participation of microRNA 124-CREB pathway: a parallel memory enhancing mechanism of standardised extract of Bacopa monniera (BESEB CDRI-08)," Neurochemical Research, vol. 37, no. 10, pp. 2167-2177, 2012.

[40] A. Das, G. Shanker, C. Nath, R. Pal, S. Singh, and H. K. Singh, "A comparative study in rodents of standardized extracts of Bacopa monniera and Ginkgo biloba-anticholinesterase and cognitive enhancing activities," Pharmacology Biochemistry and Behavior, vol. 73, no. 4, pp. 893-900, 2002.

[41] K. E. Rajan, H. K. Singh, A. Parkavi, and P. D. Charles, "Attenuation of 1-(m-chlorophenyl)-biguanide induced hippocampusdependent memory impairment by a standardised extract of Bacopa monniera (BESEB CDRI-08)," Neurochemical Research, vol. 36, no. 11, pp. 2136-2144, 2011.

[42] J. Preethi, H. K. Singh, J. S. Venkataraman, and K. E. Rajan, "Standardised extract of Bacopa monniera (CDRI-08) improves contextual fear memory by differentially regulating the activity of histone acetylation and protein phosphatases (PP1 $\alpha, \mathrm{PP} 2 \mathrm{~A})$ in hippocampus," Cellular and Molecular Neurobiology, vol. 34, no. 4, pp. 577-589, 2014.

[43] C. P. Dulcy, H. K. Singh, J. Preethi, and K. E. Rajan, "Standardized extract of Bacopa monniera (BESEB CDRI-08) attenuates contextual associative learning deficits in the aging rat's brain induced by D-galactose," Journal of Neuroscience Research, vol. 90, no. 10, pp. 2053-2064, 2012.

[44] P. Piyabhan and T. Wetchateng, "Cognitive enhancement effects of Bacopa monnieri (Brahmi) on novel object recognition and VGLUT1 density in the prefrontal cortex, striatum, and hippocampus of sub-chronic phencyclidine rat model of schizophrenia," Journal of the Medical Association of Thailand, vol. 96, no. 5, pp. 625-632, 2013.

[45] P. Piyabhan, T. Wetchateng, and S. Sirseeratawong, "Cognitive enhancement effects of Bacopa monnieri (Brahmi) on novel object recognition and NMDA receptor immunodensity in the prefrontal cortex and hippocampus of sub-chronic phencyclidine rat model of schizophrenia," Journal of the Medical Association of Thailand, vol. 96, no. 2, pp. 231-238, 2013.

[46] V. R. Vollala, S. Upadhya, and S. Nayak, "Enhanced dendritic arborization of amygdala neurons during growth spurt periods in rats orally intubated with Bacopa monniera extract," Anatomical science international, vol. 86, no. 4, pp. 179-188, 2011.

[47] V. R. Vollala, S. Upadhya, and S. Nayak, "Enhanced dendritic arborization of hippocampal CA3 neurons by Bacopa monniera extract treatment in adult rats," Romanian Journal of Morphology and Embryology, vol. 52, no. 3, pp. 879-886, 2011.

[48] K. Kishore and M. Singh, "Effect of bacosides, alcoholic extract of Bacopa monniera Linn. (brahmi), on experimental amnesia in mice," Indian Journal of Experimental Biology, vol. 43, no. 7, pp. 640-645, 2005.

[49] T. Sumathi, C. Shobana, J. Christinal, and C. Anusha, "Protective effect of Bacopa monniera on methyl mercury-induced oxidative stress in cerebellum of rats," Cellular and Molecular Neurobiology, vol. 32, no. 6, pp. 979-987, 2012.

[50] A. H. Thippeswamy, M. Rafiq, G. L. S. Viswantha, K. J. Kavya, S. D. Anturlikar, and P. S. Patki, "Evaluation of Bacopa monniera for its synergistic activity with rivastigmine in reversing aluminum-induced memory loss and learning deficit in rats," Journal of Acupuncture and Meridian Studies, vol. 6, no. 4, pp. 208-213, 2013.

[51] T. Sandhya, J. Sowjanya, and B. Veeresh, “Bacopa monniera (L.) Wettst ameliorates behavioral alterations and oxidative markers in sodium valproate induced autism in rats," Neurochemical Research, vol. 37, no. 5, pp. 1121-1131, 2012.

[52] W. M. Pardridge, "Blood-brain barrier biology and methodology," Journal of Neuro Virology, vol. 5, no. 6, pp. 556-569, 1999.

[53] K. De, S. Chandra, and M. Misra, "Evaluation of the biological effect of brahmi (Bacopa monnieri Linn) extract on the biodistribution of technetium-99m radiopharmaceuticals," Life Science Journal, vol. 5, no. 2, pp. 45-49, 2008.

[54] N. Sheikh, A. Ahmad, K. B. Siripurapu, V. K. Kuchibhotla, S. Singh, and G. Palit, "Effect of Bacopa monniera on stress induced changes in plasma corticosterone and brain monoamines in rats," Journal of Ethnopharmacology, vol. 111, no. 3, pp. 671-676, 2007.

[55] H. J. Reis, C. Guatimosim, M. Paquet et al., "Neuro-transmitters in the central nervous system and their implication in learning and memory processes," Current Medicinal Chemistry, vol. 16, no. 7, pp. 796-840, 2009.

[56] G. J. Kant, R. M. Wylie, A. A. Vasilakls, and S. Ghosh, "Effects of triazolam and diazepam on learning and memory as assessed using a water maze," Pharmacology Biochemistry and Behavior, vol. 53, no. 2, pp. 317-322, 1996.

[57] M. Morales, E. Battenberg, L. De Lecea, and F. E. Bloom, “The type 3 serotonin receptor is expressed in a subpopulation of 
GABAergic neurons in the rat neocortex and hippocampus," Brain Research, vol. 731, no. 1-2, pp. 199-202, 1996.

[58] T. J. Turner, D. J. Mokler, and J. I. Luebke, "Calcium influx through presynaptic 5-HT 3 receptors facilitates GABA release in the hippocampus: in vitro slice and synaptosome studies," Neuroscience, vol. 129, no. 3, pp. 703-718, 2004.

[59] M. M. Dorostkar and S. Boehm, "Opposite effects of presynaptic 5-HT3 receptor activation on spontaneous and action potentialevoked GABA release at hippocampal synapses," Journal of Neurochemistry, vol. 100, no. 2, pp. 395-405, 2007.

[60] M. J. Ramírez, E. Cenarruzabeitia, B. Lasheras, and J. del Río, "Involvement of GABA systems in acetylcholine release induced by $5-\mathrm{HT}_{3}$ receptor blockade in slices from rat entorhinal cortex," Brain Research, vol. 712, no. 2, pp. 274-280, 1996.

[61] M. Díez-Ariza, M. J. Ramírez, B. Lasheras, and J. Del Río, "Differential interaction between 5-HT3 receptors and GABAergic neurons inhibiting acetylcholine release in rat entorhinal cortex slices," Brain Research, vol. 801, no. 1-2, pp. 228-232, 1998.

[62] S. Consolo, R. Bertorelli, G. Russi, M. Zambelli, and H. Ladinsky, "Serotonergic facilitation of acetylcholine release in vivo from rat dorsal hippocampus via serotonin $5-\mathrm{HT}_{3}$ receptors," Journal of Neurochemistry, vol. 62, no. 6, pp. 2254-2261, 1994.

[63] F. Chamas, L. Serova, and E. L. Sabban, "Tryptophan hydroxylase mRNA levels are elevated by repeated immobilization stress in rat raphe nuclei but not in pineal gland," Neuroscience Letters, vol. 267, no. 3, pp. 157-160, 1999.

[64] S. W. Kim, S. Y. Park, and O. Hwang, "Up-regulation of tryptophan hydroxylase expression and serotonin synthesis by sertraline," Molecular Pharmacology, vol. 61, no. 4, pp. 778-785, 2002.

[65] R. R. Gainetdinov and M. G. Caron, "Monoamine transporters: from genes to behavior," Annual Review of Pharmacology and Toxicology, vol. 43, pp. 261-284, 2003.

[66] R. D. Hawkins, T. W. Abrams, T. J. Carew, and E. R. Kandel, "A cellular mechanism of classical conditioning in Aplysia: activity-dependent amplification of presynaptic facilitation," Science, vol. 219, no. 4583, pp. 400-405, 1983.

[67] A. Meneses, "5-HT system and cognition," Neuroscience and Biobehavioral Reviews, vol. 23, no. 8, pp. 1111-1125, 1999.

[68] D. M. Rajathei, J. Preethi, H. K. Singh, and K. E. Rajan, "Molecular docking of bacosides with tryptophan hydroxylase: a model to understand the bacosides mechanism," Natural Products and Bioprospecting, vol. 4, no. 4, pp. 251-255, 2014.

[69] A. Meneses, "A pharmacological analysis of an associative learning task: $5-\mathrm{HT}_{1}$ to $5-\mathrm{HT}_{7}$ receptor subtypes function on a Pavlovian/instrumental autoshaped memory," Learning and Memory, vol. 10, no. 5, pp. 363-372, 2003.

[70] H. J. Cassaday, H. Hodges, and J. A. Gray, "The effects of ritanserin, RU 24969 and 8-OH-DPAT on latent inhibition in the rat," Journal of Psychopharmacology, vol. 7, supplement 1, pp. 63-71, 1993.

[71] M.-C. Buhot, "Serotonin receptors in cognitive behaviors," Current Opinion in Neurobiology, vol. 7, no. 2, pp. 243-254, 1997.

[72] Y.-Y. Huang and E. R. Kandel, "5-Hydroxytryptamine induces a protein kinase $\mathrm{A} /$ mitogen-activated protein kinase-mediated and macromolecular synthesis-dependent late phase of longterm potentiation in the amygdala," The Journal of Neuroscience, vol. 27, no. 12, pp. 3111-3119, 2007.

[73] A. V. Harrell and A. M. Allan, "Improvements in hippocampaldependent learning and decremental attention in $5-\mathrm{HT}_{3}$ receptor overexpressing mice," Learning and Memory, vol. 10, no. 5, pp. 410-419, 2003.
[74] K. B. Fink and M. Göthert, "5-HT receptor regulation of neurotransmitter release," Pharmacological Reviews, vol. 59, no. 4, pp. 360-417, 2007.

[75] G. J. Kilpatrick, A. Butler, J. Burridge, and A. W. Oxford, "1-( $m$ Chlorophenyl)-biguanide, a potent high affinity 5-HT3 receptor agonist," European Journal of Pharmacology, vol. 182, no. 1, pp. 193-197, 1990.

[76] A. Meneses, "Stimulation of 5- $\mathrm{HT}_{1 \mathrm{~A}}, 5-\mathrm{HT}_{1 \mathrm{~B}}, 5-\mathrm{HT}_{1 \mathrm{~A} / 2 \mathrm{C}}, 5-\mathrm{HT}_{3}$ and $5-\mathrm{HT}_{4}$ receptors or 5-HT uptake inhibition: short- and long-term memory," Behavioural Brain Research, vol. 184, no. 1, pp. 81-90, 2007.

[77] M. W. Decker and J. L. McGaugh, "The role of interactions between the cholinergic system and other neuromodulatory systems in learning and memory," Synapse, vol. 7, no. 2, pp. 151$168,1991$.

[78] M. Matsukawa, M. Ogawa, K. Nakadate et al., "Serotonin and acetylcholine are crucial to maintain hippocampal synapses and memory acquisition in rats," Neuroscience Letters, vol. 230, no. 1, pp. 13-16, 1997.

[79] R. Stancampiano, S. Cocco, C. Cugusi, L. Sarais, and F. Fadda, "Serotonin and acetylcholine release response in the rat hippocampus during a spatial memory task," Neuroscience, vol. 89, no. 4, pp. 1135-1143, 1999.

[80] K. Nail-Boucherie, N. Dourmap, R. Jaffard, and J. Costentin, "Contextual fear conditioning is associated with an increase of acetylcholine release in the hippocampus of rat," Cognitive Brain Research, vol. 9, no. 2, pp. 193-197, 2000.

[81] J. A. Van Hooft and H. P. M. Vijverberg, "5-HT3 receptors and neurotransmitter release in the CNS: a nerve ending story?" Trends in Neurosciences, vol. 23, no. 12, pp. 605-610, 2000.

[82] P. Blandina, J. Goldfarb, B. Craddock-Royal, and J. P. Green, "Release of endogenous dopamine by stimulation of 5hydroxytryptamine3 receptors in rat striatum," Journal of Pharmacology and Experimental Therapeutics, vol. 251, no. 3, pp. 803-809, 1989.

[83] K. D. Alex and E. A. Pehek, "Pharmacologic mechanisms of serotonergic regulation of dopamine neurotransmission," Pharmacology and Therapeutics, vol. 113, no. 2, pp. 296-320, 2007.

[84] A. D. Campbell, D. E. Womer, and J. R. Simon, "The 5-HT3 receptor agonist 1-( $m$-chlorophenyl)-biguanide interacts with the dopamine transporter in rat brain synaptosomes," European Journal of Pharmacology: Molecular Pharmacology, vol. 290, no. 2, pp. 157-162, 1995.

[85] M. F. Siddiqui and A. I. Levey, "Cholinergic therapies in Alzheimer's disease," Drugs of the Future, vol. 24, no. 4, pp. 417424, 1999.

[86] M. Brunelli, V. Castellucci, and E. R. Kandel, "Synaptic facilitation and behavioral sensitization in Aplysia: possible role of serotonin and cyclic AMP,' Science, vol. 194, no. 4270, pp. 11781181, 1976.

[87] V. F. Castellucci, E. R. Kandel, and J. H. Schwartz, "Intracellular injection of the catalytic subunit of cyclic AMP-dependent protein kinase simulates facilitation of transmitter release underlying behavioral sensitization in Aplysia," Proceedings of the National Academy of Sciences of the United States of America, vol. 77, no. 12, pp. 7492-7496, 1980.

[88] B. J. Bacskai, B. Hochner, M. Mahaut-Smith et al., "Spatially resolved dynamics of CAMP and protein kinase a subunits in Aplysia sensory neurons," Science, vol. 260, no. 5105, pp. 222226, 1993. 
[89] K. C. Martin, D. Michael, J. C. Rose et al., "MAP kinase translocates into the nucleus of the presynaptic cell and is required for long-term facilitation in Aplysia," Neuron, vol. 18, no. 6, pp. 899-912, 1997.

[90] J. S. Villarreal and E. J. Barea-Rodriguez, "ERK phosphorylation is required for retention of trace fear memory," Neurobiology of Learning and Memory, vol. 85, no. 1, pp. 44-57, 2006.

[91] C. B. Sindreu, Z. S. Scheiner, and D. R. Storm, " $\mathrm{Ca}^{2+}$-stimulated adenylyl cyclases regulate ERK-dependent activation of MSK1 during fear conditioning," Neuron, vol. 53, no. 1, pp. 79-89, 2007.

[92] L. Restivo, E. Tafi, M. Ammassari-Teule, and H. Marie, "Viralmediated expression of a constitutively active form of CREB in hippocampal neurons increases memory," Hippocampus, vol. 19, no. 3, pp. 228-234, 2009.

[93] A. Suzuki, H. Fukushima, T. Mukawa et al., "Upregulation of CREB-mediated transcription enhances both short- and longterm memory," The Journal of Neuroscience, vol. 31, no. 24, pp. 8786-8802, 2011.

[94] S. Davis, P. Vanhoutte, C. Pagès, J. Caboche, and S. Laroche, "The MAPK/ERK cascade targets both Elk-1 and cAMP response element-binding protein to control long-term potentiation-dependent gene expression in the dentate gyrus in vivo," The Journal of Neuroscience, vol. 20, no. 12, pp. 4563-4572, 2000.

[95] H. Zhai, Y. Li, X. Wang, and L. Lu, "Drug-induced alterations in the extracellular signal-regulated kinase (ERK) signalling pathway: implications for reinforcement and reinstatement," Cellular and Molecular Neurobiology, vol. 28, no. 2, pp. 157-172, 2008.

[96] D. Bartsch, A. Casadio, K. A. Karl, P. Serodio, and E. R. Kandel, "CREB1 encodes a nuclear activator, a repressor, and a cytoplasmic modulator that form a regulatory unit critical for long-term facilitation," Cell, vol. 95, no. 2, pp. 211-223, 1998.

[97] J. C. P. Yin, M. del Vecchio, H. Zhou, and T. Tully, "CREB as a memory modulator: induced expression of a dCREB2 activator isoform enhances long-term memory in drosophila," Cell, vol. 81, no. 1, pp. 107-115, 1995.

[98] H. Zhao, Q. Li, Z. Zhang, X. Pei, J. Wang, and Y. Li, "Longterm ginsenoside consumption prevents memory loss in aged SAMP8 mice by decreasing oxidative stress and up-regulating the plasticity-related proteins in hippocampus," Brain Research, vol. 1256, pp. 111-122, 2009.

[99] E. R. Kandel, "The molecular biology of memory storage: a dialog between genes and synapses," Bioscience Reports, vol. 21, no. 5, pp. 565-611, 2001.

[100] U. Müller and T. J. Carew, "Serotonin induces temporally and mechanistically distinct phases of persistent PKA activity in Aplysia sensory neurons," Neuron, vol. 21, no. 6, pp. 1423-1434, 1998.

[101] B. Li, S. Zhang, M. Li, L. Hertz, and L. Peng, "Chronic treatment of astrocytes with therapeutically relevant fluoxetine concentrations enhances cPLA2 expression secondary to 5-HT 2Binduced, transactivation-mediated ERK1/2 phosphorylation," Psychopharmacology, vol. 207, no. 1, pp. 1-12, 2009.

[102] S. Peng, Y. Zhang, J. Zhang, H. Wang, and B. Ren, "ERK in learning and memory: a review of recent research," International Journal of Molecular Sciences, vol. 11, no. 1, pp. 222-232, 2010.

[103] C. H. Bailey, E. R. Kandel, and K. Si, "The persistence of longterm memory: a molecular approach to self-sustaining changes in learning-induced synaptic growth," Neuron, vol. 44, no. 1, pp. 49-57, 2004.
[104] R. J. Kelleher III, A. Govindarajan, and S. Tonegawa, “Translational regulatory mechanisms in persistent forms of synaptic plasticity," Neuron, vol. 44, no. 1, pp. 59-73, 2004.

[105] S. I. Ashraf, A. L. McLoon, S. M. Sclarsic, and S. Kunes, "Synaptic protein synthesis associated with memory is regulated by the RISC pathway in Drosophila," Cell, vol. 124, no. 1, pp. 191205, 2006.

[106] G. A. Wayman, M. Davare, H. Ando et al., "An activity-regulated microRNA controls dendritic plasticity by down-regulating p250GAP," Proceedings of the National Academy of Sciences of the United States of America, vol. 105, no. 26, pp. 9093-9098, 2008.

[107] N. R. Smalheiser and G. Lugli, "MicroRNA regulation of synaptic plasticity," Neuromolecular Medicine, vol. 11, no. 3, pp. 133-140, 2009.

[108] G. Lugli, J. Larson, M. E. Martone, Y. Jones, and N. R. Smalheiser, "Dicer and eIF2c are enriched at postsynaptic densities in adult mouse brain and are modified by neuronal activity in a calpain-dependent manner," Journal of Neurochemistry, vol. 94, no. 4, pp. 896-905, 2005.

[109] P. Rajasethupathy, F. Fiumara, R. Sheridan et al., "Characterization of small RNAs in Aplysia reveals a role for miR-124 in constraining synaptic plasticity through CREB," Neuron, vol. 63, no. 6, pp. 803-817, 2009.

[110] W. Konopka, A. Kiryk, M. Novak et al., "MicroRNA loss enhances learning and memory in mice," The Journal of Neuroscience, vol. 30, no. 44, pp. 14835-14842, 2010.

[111] I. Y. C. Liu, W. E. Lyons, L. A. Mamounas, and R. F. Thompson, "Brain-derived neurotrophic factor plays a critical role in contextual fear conditioning," The Journal of Neuroscience, vol. 24, no. 36, pp. 7958-7963, 2004.

[112] R.-Y. Liu, D. Fioravante, S. Shah, and J. H. Byrne, "cAMP response element-binding protein 1 feedback loop is necessary for consolidation of long-term synaptic facilitation in Aplysia," Journal of Neuroscience, vol. 28, no. 8, pp. 1970-1976, 2008.

[113] B. P. Lewis, I.-H. Shih, M. W. Jones-Rhoades, D. P. Bartel, and C. B. Burge, "Prediction of mammalian microRNA targets," Cell, vol. 115, no. 7, pp. 787-798, 2003.

[114] J. Winter, S. Jung, S. Keller, R. I. Gregory, and S. Diederichs, "Many roads to maturity: microRNA biogenesis pathways and their regulation," Nature Cell Biology, vol. 11, no. 3, pp. 228-234, 2009.

[115] G. Siegel, R. Saba, and G. Schratt, "MicroRNAs in neurons: manifold regulatory roles at the synapse," Current Opinion in Genetics and Development, vol. 21, no. 4, pp. 491-497, 2011.

[116] M. J. Millan, "MicroRNA in the regulation and expression of serotonergic transmission in the brain and other tissues," Current Opinion in Pharmacology, vol. 11, no. 1, pp. 11-22, 2011.

[117] C. M. Alberini, M. Ghirardi, R. Metz, and E. R. Kandel, “C/EBP is an immediate-early gene required for the consolidation of long-term facilitation in Aplysia," Cell, vol. 76, no. 6, pp. 10991114, 1994.

[118] B. E. Lonze and D. D. Ginty, "Function and regulation of CREB family transcription factors in the nervous system," Neuron, vol. 35, no. 4, pp. 605-623, 2002.

[119] Y.-S. Lee and A. J. Silva, "The molecular and cellular biology of enhanced cognition," Nature Reviews Neuroscience, vol. 10, no. 2, pp. 126-140, 2009.

[120] D. Genoux, U. Haditsch, M. Knobloch, A. Michalon, D. Storm, and I. M. Mansuy, "Protein phosphatase 1 is a molecular constraint on learning and memory," Nature, vol. 418, no. 6901, pp. 970-975, 2002. 
[121] I. M. Mansuy and S. Shenolikar, "Protein serine/threonine phosphatases in neuronal plasticity and disorders of learning and memory", Trends in Neurosciences, vol. 29, no. 12, pp. 679686, 2006.

[122] M. Knobloch, M. Farinelli, U. Konietzko, R. M. Nitsch, and I. M. Mansuy, "A $\beta$ oligomer-mediated long-term potentiation impairment involves protein phosphatase 1-dependent mechanisms," Journal of Neuroscience, vol. 27, no. 29, pp. 7648-7653, 2007.

[123] K. Koshibu, J. Gräff, M. Beullens et al., "Protein phosphatase 1 regulates the histone code for long-term memory," The Journal of Neuroscience, vol. 29, no. 41, pp. 13079-13089, 2009.

[124] K. Koshibu, J. Gräff, and I. M. Mansuy, "Nuclear protein phosphatase-1: an epigenetic regulator of fear memory and amygdala long-term potentiation," Neuroscience, vol. 173, pp. 30-36, 2011.

[125] J. C. Mauna, T. Miyamae, B. Pulli, and E. Thiels, "Protein phosphatases 1 and $2 \mathrm{~A}$ are both required for long-term depression and associated dephosphorylation of cAMP response element binding protein in hippocampal area CA1 in vivo," Hippocampus, vol. 21, no. 10, pp. 1093-1104, 2011.

[126] D. Genoux, P. Bezerra, and J. M. Montgomery, "Intra-spaced stimulation and protein phosphatase 1 dictate the direction of synaptic plasticity," The European Journal of Neuroscience, vol. 33, no. 10, pp. 1761-1770, 2011.

[127] D. L. Oberbeck, S. McCormack, and T. A. Houpt, "Intraamygdalar okadaic acid enhances conditioned taste aversion learning and CREB phosphorylation in rats," Brain Research, vol. 1348, pp. 84-94, 2010.

[128] M. Peters, M. Bletsch, R. Catapano, X. Zhang, T. Tully, and R. Bourtchouladze, "RNA interference in hippocampus demonstrates opposing roles for CREB and PP1 $\alpha$ in contextual and temporal long-term memory," Genes, Brain and Behavior, vol. 8, no. 3, pp. 320-329, 2009.

[129] Y.-Y. Yin, H. Liu, X.-B. Cong et al., "Acetyl-L-carnitine attenuates okadaic acid induced tau hyperphosphorylation and spatial memory impairment in rats," Journal of Alzheimer's Disease, vol. 19, no. 2, pp. 735-746, 2010.

[130] X. Wang, T. Takata, X. Bai, F. Ou, K. Yokono, and T. Sakurai, "Pyruvate prevents the inhibition of the long-term potentiation induced by amyloid- $\beta$ through protein phosphatase $2 \mathrm{~A}$ inactivation," Journal of Alzheimer's Disease, vol. 30, no. 3, pp. 665673, 2012.

[131] Z. Guan, M. Giustetto, S. Lomvardas et al., "Integration of longterm-memory-related synaptic plasticity involves bidirectional regulation of gene expression and chromatin structure," Cell, vol. 111, no. 4, pp. 483-493, 2002.

[132] J. M. Levenson and J. D. Sweatt, "Epigenetic mechanisms in memory formation," Nature Reviews Neuroscience, vol. 6, no. 2, pp. 108-118, 2005.

[133] J. Hsieh and F. H. Gage, "Chromatin remodeling in neural development and plasticity," Current Opinion in Cell Biology, vol. 17, no. 6, pp. 664-671, 2005.

[134] G. Canettieri, I. Morantte, E. Guzmán et al., "Attenuation of a phosphorylation-dependent activator by an HDAC-PP1 complex," Nature Structural Biology, vol. 10, no. 3, pp. 175-181, 2003.

[135] J. M. Levenson, K. J. O’Riordan, K. D. Brown, M. A. Trinh, D. L. Molfese, and J. D. Sweatt, "Regulation of histone acetylation during memory formation in the hippocampus," The Journal of Biological Chemistry, vol. 279, no. 39, pp. 40545-40559, 2004.
[136] E. Korzus, M. G. Rosenfeld, and M. Mayford, "CBP histone acetyltransferase activity is a critical component of memory consolidation," Neuron, vol. 42, no. 6, pp. 961-972, 2004.

[137] H. Asahara, B. Santoso, E. Guzman et al., "Chromatindependent cooperativity between constitutive and inducible activation domains in CREB," Molecular and Cellular Biology, vol. 21, no. 23, pp. 7892-7900, 2001.

[138] J. R. Lundblad, R. P. S. Kwok, M. E. Laurance, M. L. Harter, and R. H. Goodman, "Adenoviral E1A-associated protein p300 as a functional homologue of the transcriptional co-activator CBP," Nature, vol. 374, no. 6517, pp. 85-88, 1995.

[139] H. M. Chan and N. B. La Thangue, "p300/CBP proteins: HATs for transcriptional bridges and scaffolds," Journal of Cell Science, vol. 114, no. 13, pp. 2363-2373, 2001.

[140] N. Vo and R. H. Goodman, "CREB-binding protein and p300 in transcriptional regulation," Journal of Biological Chemistry, vol. 276, no. 17, pp. 13505-13508, 2001.

[141] A. M. M. Oliveira, M. A. Wood, C. B. McDonough, and T. Abel, "Transgenic mice expressing an inhibitory truncated form of p300 exhibit long-term memory deficits," Learning and Memory, vol. 14, no. 9, pp. 564-572, 2007.

[142] A. M. M. Oliveira, M. A. Estévez, J. D. Hawk, S. Grimes, P. K. Brindle, and T. Abel, "Subregion-specific p300 conditional knock-out mice exhibit long-term memory impairments," Learning and Memory, vol. 18, no. 3, pp. 161-169, 2011.

[143] R. Marek, C. M. Coelho, R. K. P. Sullivan et al., "Paradoxical enhancement of fear extinction memory and synaptic plasticity by inhibition of the histone acetyltransferase p300," The Journal of Neuroscience, vol. 31, no. 20, pp. 7486-7491, 2011.

[144] V. V. Ogryzko, R. L. Schiltz, V. Russanova, B. H. Howard, and Y. Nakatani, "The transcriptional coactivators p300 and CBP are histone acetyltransferases," Cell, vol. 87, no. 5, pp. 953-959, 1996.

[145] R. L. Schiltz, C. A. Mizzen, A. Vassilev, R. G. Cook, C. D. Allis, and Y. Nakatani, "Overlapping but distinct patterns of histone acetylation by the human coactivators p300 and PCAF within nucleosomal substrates," The Journal of Biological Chemistry, vol. 274, no. 3, pp. 1189-1192, 1999.

[146] K. J. McManus and M. J. Hendzel, "Quantitative analysis of CBP- and P300-induced histone acetylations in vivo using native chromatin," Molecular and Cellular Biology, vol. 23, no. 21, pp. 7611-7627, 2003.

[147] C. G. Vecsey, J. D. Hawk, K. M. Lattal et al., "Histone deacetylase inhibitors enhance memory and synaptic plasticity via CREB: CBP-dependent transcriptional activation," The Journal of Neuroscience, vol. 27, no. 23, pp. 6128-6140, 2007.

[148] C. Sanchis-Segura, J. P. Lopez-Atalaya, and A. Barco, "Selective boosting of transcriptional and behavioral responses to drugs of abuse by histone deacetylase inhibition," Neuropsychopharmacology, vol. 34, no. 13, pp. 2642-2654, 2009.

[149] M. Kilgore, C. A. Miller, D. M. Fass et al., "Inhibitors of class 1 histone deacetylases reverse contextual memory deficits in a mouse model of alzheimer's disease," Neuropsychopharmacology, vol. 35, no. 4, pp. 870-880, 2010.

[150] Y. Itzhak, K. L. Anderson, J. B. Kelley, and M. Petkov, "Histone acetylation rescues contextual fear conditioning in nNOS KO mice and accelerates extinction of cued fear conditioning in wild type mice," Neurobiology of Learning and Memory, vol. 97, no. 4, pp. 409-417, 2012.

[151] P. Washbourne, A. Dityatev, P. Scheiffele et al., "Cell adhesion molecules in synapse formation," The Journal of Neuroscience, vol. 24, no. 42, pp. 9244-9249, 2004. 
[152] A. M. Craig, E. R. Graf, and M. W. Linhoff, "How to build a central synapse: clues from cell culture," Trends in Neurosciences, vol. 29, no. 1, pp. 8-20, 2006.

[153] A. Nakhost, G. Houeland, V. F. Castellucci, and W. S. Sossin, "Differential regulation of transmitter release by alternatively spliced forms of synaptotagmin I," The Journal of Neuroscience, vol. 23, no. 15, pp. 6238-6244, 2003.

[154] T. L. Schwarz, "Synaptotagmin promotes both vesicle fusion and recycling," Proceedings of the National Academy of Sciences of the United States of America, vol. 101, no. 47, pp. 16401-16402, 2004.

[155] M. R. Holahan, J. L. Rekart, J. Sandoval, and A. Routtenberg, "Spatial learning induces presynaptic structural remodeling in the hippocampal mossy fiber system of two rat strains," Hippocampus, vol. 16, no. 6, pp. 560-570, 2006.

[156] D. Sun, M. J. McGinn, Z. Zhou, H. B. Harvey, M. R. Bullock, and R. J. Colello, "Anatomical integration of newly generated dentate granule neurons following traumatic brain injury in adult rats and its association to cognitive recovery," Experimental Neurology, vol. 204, no. 1, pp. 264-272, 2007.

[157] D. J. Petersen, X. Chen, L. Vinade et al., "Distribution of postsynaptic density (PSD)-95 and $\mathrm{Ca}^{2+} /$ calmodulin-dependent protein kinase II at the PSD," The Journal of Neuroscience, vol. 23, no. 35, pp. 11270-11278, 2003.

[158] A. Barria and R. Malinow, "NMDA receptor subunit composition controls synaptic plasticity by regulating binding to CaMKII," Neuron, vol. 48, no. 2, pp. 289-301, 2005.

[159] S. Vaynman, Z. Ying, and F. Gomez-Pinilla, "The select action of hippocampal calcium calmodulin protein kinase II in mediating exercise-enhanced cognitive function," Neuroscience, vol. 144, no. 3, pp. 825-833, 2007.

[160] A. Barria, D. Muller, V. Derkach, L. C. Griffith, and T. R. Soderling, "Regulatory phosphorylation of AMPA-type glutamate receptors by CaM-KII during long-term potentiation," Science, vol. 276, no. 5321, pp. 2042-2045, 1997.

[161] S. Moyano, J. Del Río, and D. Frechilla, "Role of hippocampalCaMKII in serotonin 5- $\mathrm{HT}_{\mathrm{Al}}$ receptor-mediated learning deficit in rats," Neuropsychopharmacology, vol. 29, no. 12, pp. 22162224, 2004.

[162] K. G. Achterberg, G. H. Buitendijk, M. J. Kool et al., “Temporal and region-specific requirements of $\alpha$ CaMKII in spatial and contextual learning," The Journal of Neuroscience, vol. 34, no. 34, pp. 11180-11187, 2014.

[163] Y. Hata and Y. Takai, "Roles of postsynaptic density-95/synapseassociated protein 90 and its interacting proteins in the organization of synapses," Cellular and Molecular Life Sciences, vol. 56, no. 5-6, pp. 461-472, 1999.

[164] I. Nikonenko, B. Boda, S. Steen, G. Knott, E. Welker, and D. Muller, "PSD-95 promotes synaptogenesis and multiinnervated spine formation through nitric oxide signaling," The Journal of Cell Biology, vol. 183, no. 6, pp. 1115-1127, 2008.

[165] C. C. Garner, J. Nash, and R. L. Huganir, "PDZ domains in synapse assembly and signalling," Trends in Cell Biology, vol. 10, no. 7, pp. 274-280, 2000.

[166] E. I. Charych, B. F. Akum, J. S. Goldberg et al., "Activityindependent regulation of dendrite patterning by postsynaptic density protein PSD-95," The Journal of Neuroscience, vol. 26, no. 40, pp. 10164-10176, 2006.

[167] A. Skibinska, M. Lech, and M. Kossut, "PSD95 protein level rises in murine somatosensory cortex after sensory training," NeuroReport, vol. 12, no. 13, pp. 2907-2910, 2001.
[168] A. Yoshii, M. H. Sheng, and M. Constantine-Paton, "Eye opening induces a rapid dendritic localization of PSD-95 in central visual neurons," Proceedings of the National Academy of Sciences of the United States of America, vol. 100, no. 3, pp. 13341339, 2003.

[169] J. F. Sturgill, P. Steiner, B. L. Czervionke, and B. L. Sabatini, "Distinct domains within PSD-95 mediate synaptic incorporation, stabilization, and activity-dependent trafficking," The Journal of Neuroscience, vol. 29, no. 41, pp. 12845-12854, 2009.

[170] A. E.-D. El-Husseini, E. Schnell, D. M. Chetkovich, R. A. Nicoll, and D. S. Bredt, "PSD-95 involvement in maturation of excitatory synapses," Science, vol. 290, no. 5495, pp. 1364-1368, 2000.

[171] S. Tomita, R. A. Nicoll, and D. S. Bredt, "PDZ protein interactions regulating glutamate receptor function and plasticity," The Journal of Cell Biology, vol. 153, no. 5, pp. F19-F23, 2001.

[172] Q. J. Sun, R. S. Duan, A. H. Wang et al., "Alterations of NR2B and PSD-95 expression in hippocampus of kainic acid-exposed rats with behavioural deficits," Behavioural Brain Research, vol. 201, no. 2, pp. 292-299, 2009. 


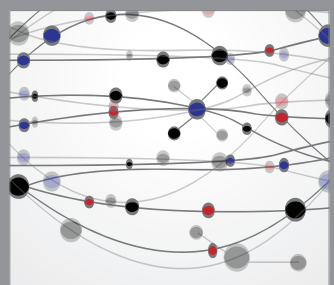

The Scientific World Journal
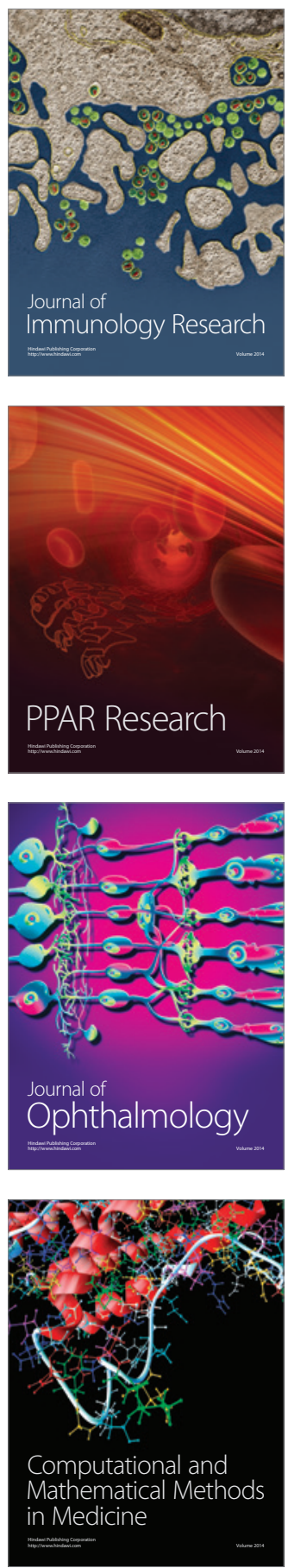

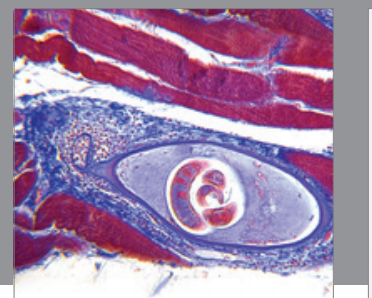

Gastroenterology

Research and Practice
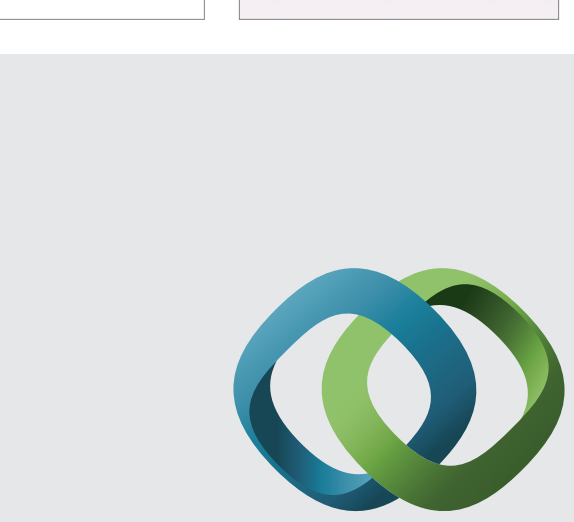

\section{Hindawi}

Submit your manuscripts at

http://www.hindawi.com
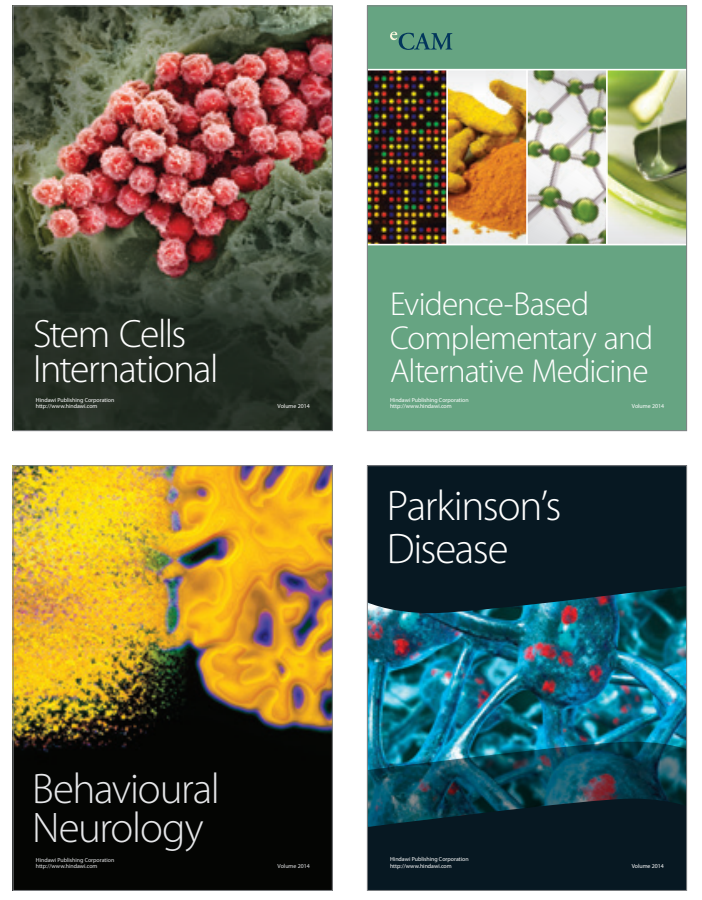
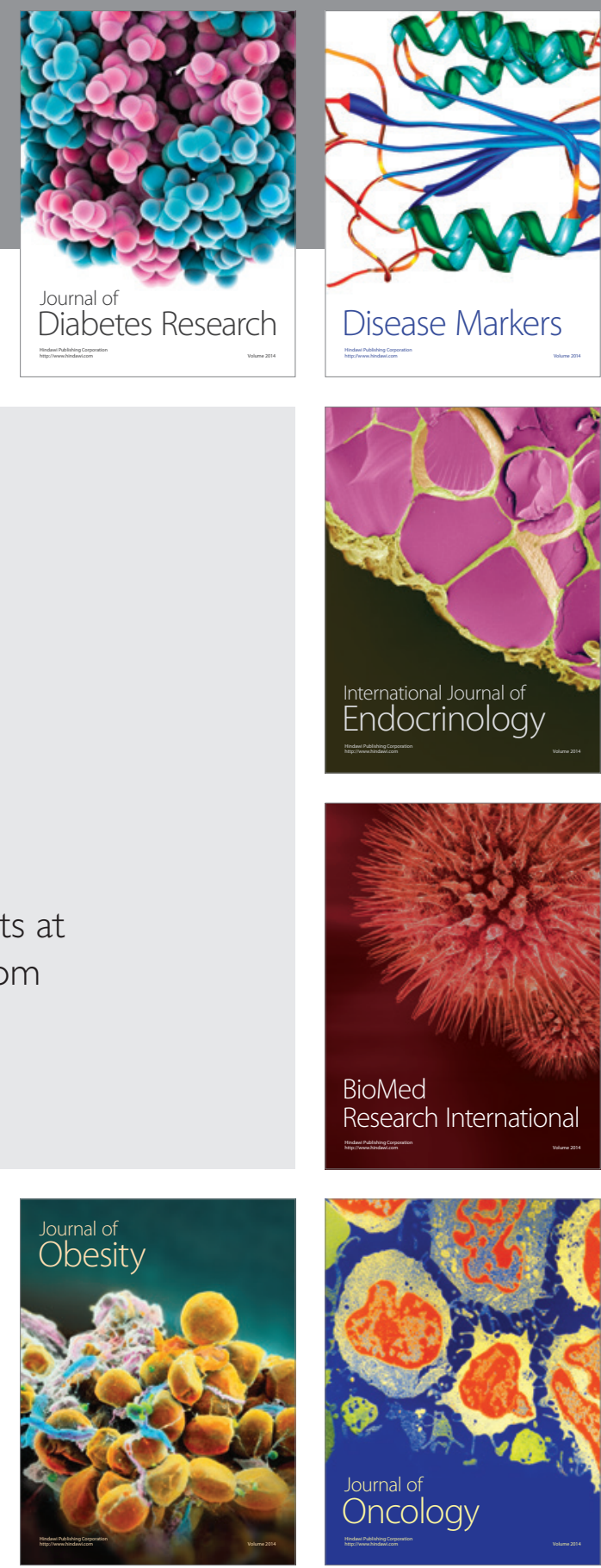

Disease Markers
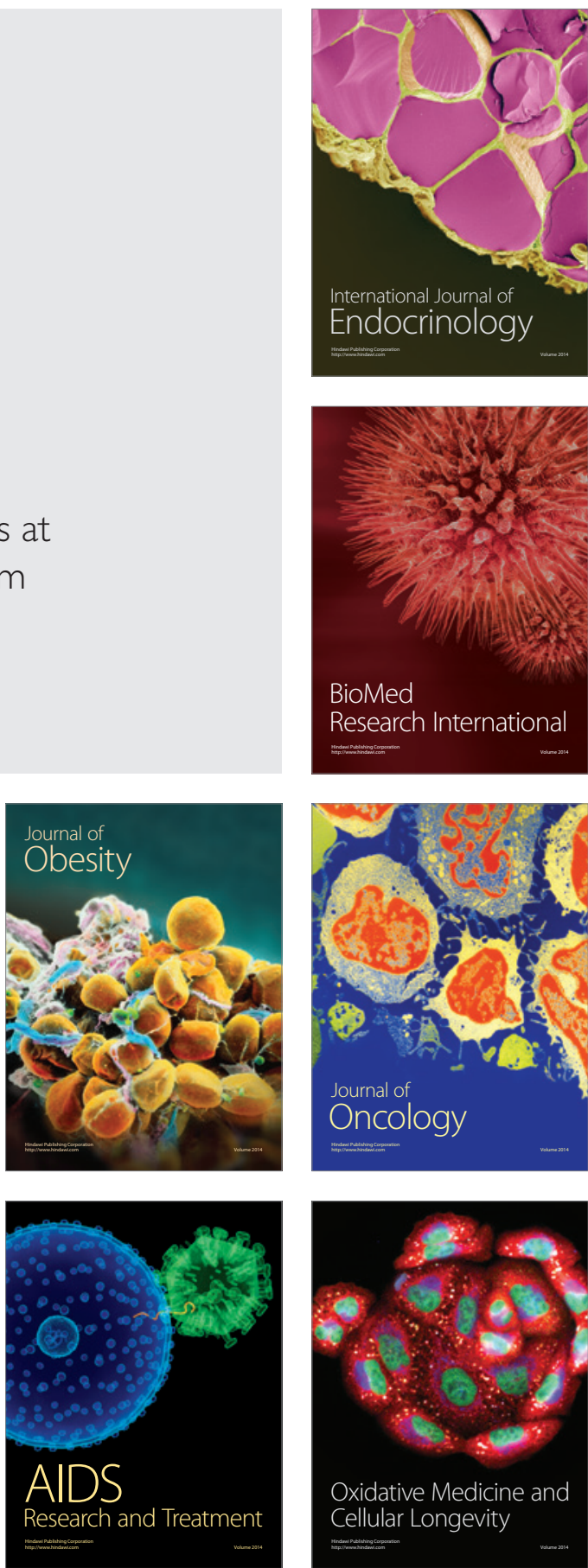